\title{
Enhanced Ionic Conduction in Organoboron Ion Gels Facilely Designed via Condensation of Cellulose with Boric Acids in Ionic Liquids
}

\author{
By Noriyoshi MATSUMI,${ }^{1, *}$ Yusuke NAKAMURA,${ }^{1}$ Keigo AOI, ${ }^{1}$ \\ Takeshi WATANABE, ${ }^{2}$ Tomonobu MIZUMO, ${ }^{2}$ and Hiroyuki OHNO ${ }^{2}$
}

Novel ion-gels bearing lithium borate were synthesized via condensation between cellulose and boric acids in IL. Ion-gels obtained showed high ionic conductivity comparable to IL itself. First, ion-gels containing $5 \mathrm{wt} \%$ and $7 \mathrm{wt} \%$ of cellulose were prepared in 1-allyl-3-ethylimidazolium chloride. Their ionic conductivities were evaluated by ac-impedance method after drying ion-gels thoroughly. The ion-gel including $5 \mathrm{wt} \%$ of cellulose exhibited higher conductivity than that including $7 \mathrm{wt} \%$ of cellulose. This should be because of lower activating energy under lower composition of cellulose. The effect of concentration of $\mathrm{C}_{6} \mathrm{~F}_{5} \mathrm{~B}(\mathrm{OH})_{2}$ on ionic conductivity was also examined with varying the ratio of $\mathrm{B}(\mathrm{OH})_{3}$ and $\mathrm{C}_{6} \mathrm{~F}_{5} \mathrm{~B}(\mathrm{OH})_{2}$. It was demonstrated that the ion-gel including greater amount of pentafluorophenylborate showed significantly enhanced ionic conductivity. Preparation of ion-gels including 1-allyl-3-ethylimidazolium formate was also examined at the cellulose concentration of $7 \mathrm{wt} \%$. The ion-gels synthesized in 1-allyl-3-ethylimidazolium formate showed higher ionic conductivity $\left(1.98 \times 10^{-3} \mathrm{Scm}^{-1} ; 30^{\circ} \mathrm{C}\right)$ than that synthesized in 1-allyl-3-ethylimidazolium chloride. This should be because of lower viscosity of 1-allyl-3-ethylimidazolium formate.

KEY WORDS: Ion-gels / Cellulose / Boric Esters / Ionic Conduction / Ionic Liquids /

After ionic liquids (ILs) ${ }^{1-3}$ emerged as a new class of electrolytes showing unusually high ionic conductivity, ILs had become one of the most frequently employed ion conductive matrix in an amazingly short period. Expectation toward ILs as electrolyte for lithium secondary battery or fuel cell had also rapidly spread worldwide. These days, there is urgent social demanding for improvement in safety of energy storage devices. Non flammable ILs are expected to be one of key materials for the solution of such problem. To explore novel ILs showing desirable properties such as low viscosity, high electrochemical stability and selectivity of target cation transport, versatile types of ILs have been developed so far. Moreover, in view of application for energy storage devices, polymerized ILs and polymer gel electrolytes including ILs (ion gels) have also been earnestly studied. ${ }^{4-15}$ In the present work, cellulose was employed as a supporting polymer of ion gels.

In the case of poly(ethylene oxide), it is known that addition of cellulose leads to improved mechanical properties and higher ionic conductivity of the resulting matrix. ${ }^{16}$ Since chloride type ILs are known as good solvent of cellulose, ${ }^{17-19}$ preparation of IL based ion gels including cellulose appears to be a promising approach to obtain dimensionally stable and highly ion conductive ion gels.

In addition, it is widely known that poly(saccharide)s possess high reactivity toward boric acids. ${ }^{20-22}$ As an approach to improve the selectivity of target cation transport in electro- lytes or enhance ionic conductivity of matrix, incorporation of organoboron units such as boric ester, alkylborane, dissociable lithium borate proved to be valuable approach. In early stage of these researches, MacBreen et al. reported that ionic conductivity of liquid electrolytes is significantly enhanced when low molecular weight organoboron compounds such as boric ester were added to the matrix..$^{23,24}$ This concept was extended to solid polymer electrolytes by several research groups. ${ }^{25-29}$ Incorporation of organoboron unit into polymer electrolyte resulted in improved lithium transference number of the matrix. The anion trapping of boron atom worked much efficiently in IL matrix than was observed in polyether systems. ${ }^{30}$ Incorporation of several highly dissociable organoborate lithium salt structures into electrolyte matrix was particularly found to be effective to improve ionic conductivity. ${ }^{28,29,31-35}$ For instance, a zwitterionic molten salt ${ }^{32}$ bearing lithium pentafluorophenylborate structure showed very high ionic conductivity as a zwitterionic molten salt.

In the present work, design of organoboron ion gels was facilely examined by condensation of cellulose with boric acids in ILs (Scheme 1). For reasons stated above, this method would provide a convenient and effective approach for dimensionally stable and highly ion conductive ion gels that includes dissociable lithium borate structure. In this approach, it should be also noted that lithium borate structure is stable enough to allow a wide range of industrial applications.

\footnotetext{
${ }^{1}$ Graduate School of Bioagricultural Sciences, Nagoya University, Furo-cho, Chikusa-ku, Nagoya 464-8601, Japan

${ }^{2}$ Department of Biotechnology, Tokyo University of Agriculture and Technology, Koganei 184-8588, Japan

*To whom correspondence should be addressed (Tel: +81-52-789-4138, Fax: +81-52-789-4141, E-mail: matsumi@agr.nagoya-u.ac.jp).
} 


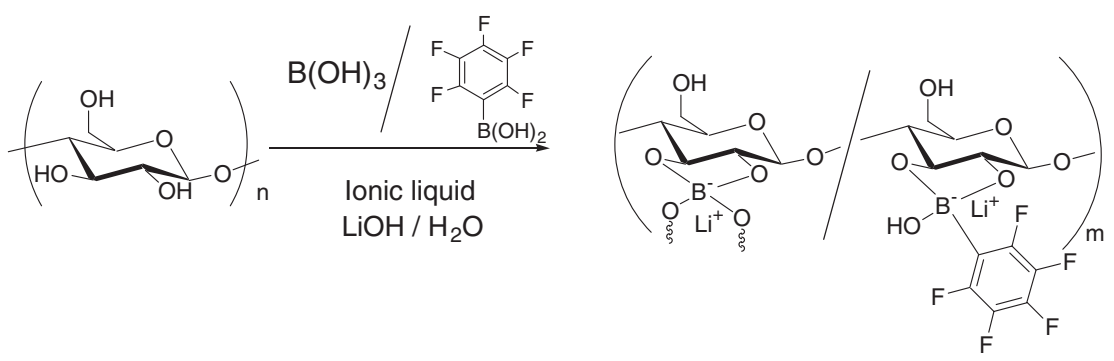

Scheme 1. Synthesis of organoboron ion gel.

\section{EXPERIMENT}

\section{Materials and Instruments}

1-Allyl-3-ethylimidazolium chloride ${ }^{18}$ and 1-allyl-3-ethylimidazolium formate ${ }^{36}$ were prepared according to the reported methods. Microcrystalline powder of cellulose was purchased from Kishida Co. Ltd. and used without further purification. Boric acid purchased from Aldrich and pentafluorophenylboronic acid purchased from Kishida Co. Ltd. were used without further purification. Lithium hydroxide was purchased from Kishida Co. Ltd. and used without further purification.

Ionic conductivity was measured with a complex-impedance gain-phase analyzer (Solartron model 1260; Schlumberger) in the frequency range from $1 \mathrm{~Hz}$ to $1 \mathrm{MHz}$. The ion gels were thoroughly dried under vacuum at $60^{\circ} \mathrm{C}$ for $24 \mathrm{~h}$ prior to the measurements. The sample was sandwiched in a custom designed cell constructed with a pair of stainless steel plates using a polypropylene spacer.

\section{Preparation of Organoboron Ion-Gels}

A typical procedure for the preparation of an organoboron ion-gel is described as follows. To $2.42 \mathrm{~g}$ of 1-allyl-3-ethylimidazolium chloride, $182 \mathrm{mg}(1.12 \mathrm{mmol})$ of crystalline powder of cellulose ( $7 \mathrm{wt} \%$ of cellulose in IL) was dissolved by heating the mixture to $90^{\circ} \mathrm{C}$. Then, $30.9 \mathrm{mg}(0.50 \mathrm{mmol})$ of boric acid, $53.0 \mathrm{mg}(0.25 \mathrm{mmol})$ of pentafluorophenylboric acid, $0.75 \mathrm{~mL}$ of $1.0 \mathrm{M}$ aqueous solution of $\mathrm{LiOH}$ were added to the solution and the resulting mixture was reacted at $90^{\circ} \mathrm{C}$ for $4 \mathrm{~h}$ under magnetic stirring. The mixture was gradually converted to a soft yellowish gel.

\section{RESULTS AND DISCUSSION}

Generally, condensation of diol with boric acid proceeds smoothly under basic aqueous solution..$^{21,22}$ Hence, condensation of cellulose with boric acid in ILs was examined after addition of aqueous solution of lithium hydroxide. This is also to introduce lithium cation as counter cation of borate units. As a chloride type IL, 1-allyl-3-ethylimidazolium chloride was employed because of relatively low viscosity of allylimidazolium type ILs.

First of all, reaction condition of ion gel formation was carefully optimized. The best results were obtained when the mixtures were heated at $90{ }^{\circ} \mathrm{C}$ for $4 \mathrm{~h}$. To ionic liquid,

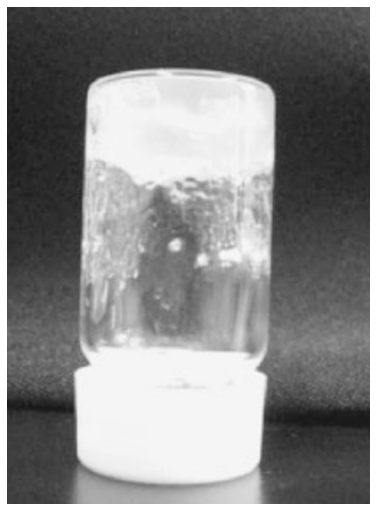

Figure 1. A photograph of ion gel including $7 \mathrm{wt} \%$ of cellulose.

designated amount of cellulose, boric acids $\left[\mathrm{B}(\mathrm{OH})_{3} / \mathrm{C}_{6} \mathrm{~F}_{5}\right.$ $\left.\mathrm{B}(\mathrm{OH})_{2}\right]$ and aqueous solution of $\mathrm{LiOH}$ were added, and then the resulting mixture was thermally treated. In the presence of $7 \mathrm{wt} \%$ of cellulose, ion gels were facilely obtained under a wide range of reaction conditions (Figure 1), while gelation was not always observed under some conditions at the cellulose composition of $5 \mathrm{wt} \%$. The composition of all the ion gels obtained in this study is summarized in Table I.

Ionic conductivity of obtained ion gels was evaluated by ac impedance method after drying the ion gels thoroughly. The obtained ion gels showed ionic conductivity of $10^{-3}-10^{-4}$ $\mathrm{Scm}^{-1}$, which is comparable to that of ionic liquids themselves (1-allyl-3-ethylimidazolium chloride; $5.88 \times 10^{-4} \mathrm{Scm}^{-1}$ at $303 \mathrm{~K}$, 1-allyl-3-ethylimidazolium formate; $1.74 \times 10^{-3}$ $\mathrm{Scm}^{-1}$ at $303 \mathrm{~K}$ ). This demonstrates that continuous ion conductive path was formed in the ion gel matrix.

First, the dependence of ionic conductivity was studied as a function of cellulose composition (Figure 2(i)). The VFT (Vogel-Fulcher-Tamman) plots ${ }^{37-39}$ were also fitted for the ion gels to obtain further information on ionic conduction (Figure 3).

$$
\sigma(T)=\frac{\mathrm{A}}{\sqrt{T}} \exp \left(\frac{-B}{T-T_{0}}\right)
$$

In the VFT equation shown above, parameters $\mathrm{A}$ and $\mathrm{B}$ correspond to carrier ion number in matrix and activation energy for ion transport, respectively. $T_{0}$ is ideal glass transition temperature of matrix which was optimized to give linear VFT plot. 
Table I. Composition of ion gels obtained in the present study

\begin{tabular}{|c|c|c|c|c|}
\hline Sample & Amount of Cellulose in IL & IL & $\mathrm{B}(\mathrm{OH})_{3}$ :glucose unit & $\mathrm{B}(\mathrm{OH})_{3}: \mathrm{C}_{6} \mathrm{~F}_{5} \mathrm{~B}(\mathrm{OH})_{2}: \mathrm{LiOH}$ \\
\hline A & 5 wt $\%$ & {$[\mathrm{AEIm}][\mathrm{Cl}]$} & $1: 4$ & $1: 2: 3$ \\
\hline B & 7 wt $\%$ & {$[\mathrm{AEIm}][\mathrm{Cl}]$} & $1: 4$ & $1: 2: 3$ \\
\hline C & 7 wt $\%$ & {$[\mathrm{AEIm}][\mathrm{Cl}]$} & $9: 20$ & $2: 1: 3$ \\
\hline $\mathrm{D}$ & 7 wt $\%$ & {$[\mathrm{AEIm}][\mathrm{Cl}]$} & 9:20 & $1: 2: 3$ \\
\hline$E$ & 7 wt $\%$ & [AEIm] $[\mathrm{HCOO}]$ & $11: 50$ & $1: 0: 1$ \\
\hline $\mathrm{F}$ & 7 wt $\%$ & {$[\mathrm{AEIm}][\mathrm{Cl}]$} & $11: 50$ & $1: 0: 1$ \\
\hline $\mathrm{G}$ & 7 wt $\%$ & [AEIm] $[\mathrm{HCOO}]$ & 9:20 & $2: 1: 3$ \\
\hline $\mathrm{H}$ & 7 wt $\%$ & {$[\mathrm{AEIm}][\mathrm{HCOO}]$} & $9: 40$ & $1: 2: 3$ \\
\hline
\end{tabular}
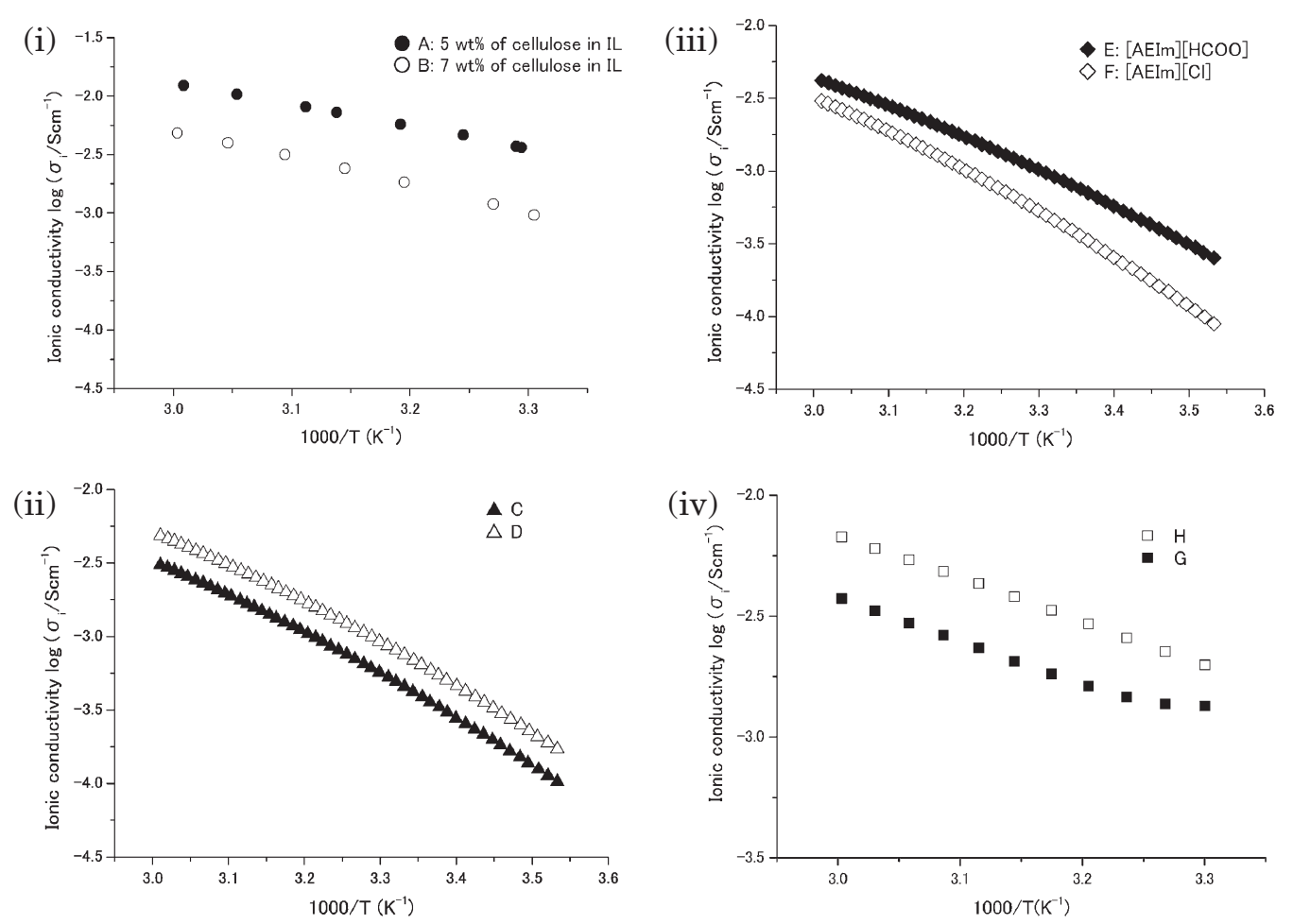

Figure 2. Temperature dependence of ionic conductivity for ion gels.

(i) Samples $A$ and $B$ contain $5 w t \%$ and $7 w t \%$ of cellulose in $[A E I m][C l]$, respectively. $\left(B(O H)_{3}:\right.$ glucose unit $\left.=1: 4, B(O H)_{3}: \mathrm{C}_{6} \mathrm{~F}_{5} \mathrm{~B}(\mathrm{OH})_{2}: \mathrm{LiOH}=1: 2: 3\right)$ (ii) All the samples contain $7 \mathrm{wt} \%$ of cellulose in $[\mathrm{AEIm}][\mathrm{Cl}]$.

Sample C; $\mathrm{B}(\mathrm{OH})_{3}:$ glucose unit $=9: 20, \mathrm{~B}(\mathrm{OH})_{3}: \mathrm{C}_{6} \mathrm{~F}_{5} \mathrm{~B}(\mathrm{OH})_{2}: \mathrm{LiOH}=2: 1: 3$.

Sample D; $\mathrm{B}(\mathrm{OH})_{3}:$ glucose unit $=9: 20, \mathrm{~B}(\mathrm{OH})_{3}: \mathrm{C}_{6} \mathrm{~F}_{5} \mathrm{~B}(\mathrm{OH})_{2}: \mathrm{LiOH}=1: 2: 3$.

(iii) Sample $E$ contains $7 \mathrm{wt} \%$ of cellulose in $[\mathrm{AEIm}][\mathrm{HCOO}]\left(\mathrm{B}(\mathrm{OH})_{3}:\right.$ glucose unit $\left.=11: 50, \mathrm{~B}(\mathrm{OH})_{3}: \mathrm{LiOH}=1: 1\right)$.

Sample F contains $7 \mathrm{wt} \%$ of cellulose in $[\mathrm{AEIm}][\mathrm{Cl}]\left(\mathrm{B}(\mathrm{OH})_{3}\right.$ :glucose unit $\left.=11: 50, \mathrm{~B}(\mathrm{OH})_{3}: \mathrm{LiOH}=1: 1\right)$.

(iv) Sample G contains 7 wt \% of cellulose in [AEIm] $[\mathrm{HCOO}]\left(\mathrm{B}(\mathrm{OH})_{3}:\right.$ glucose unit $\left.=9: 20, \mathrm{~B}(\mathrm{OH})_{3}: \mathrm{C}_{6} \mathrm{~F}_{5} \mathrm{~B}(\mathrm{OH})_{2}: \mathrm{LiOH}=2: 1: 3\right)$.

Sample $\mathrm{H}$ contains $7 \mathrm{wt} \%$ of cellulose in $[\mathrm{AEIm}][\mathrm{HCOO}]\left(\mathrm{B}(\mathrm{OH})_{3}:\right.$ glucose unit $\left.=9: 40, \mathrm{~B}(\mathrm{OH})_{3}: \mathrm{C}_{6} \mathrm{~F}_{5} \mathrm{~B}(\mathrm{OH})_{2}: \mathrm{LiOH}=1: 2: 3\right)$.

The ionic conductivity of ion gel containing $5 \mathrm{wt} \%$ of cellulose (sample A) was significantly higher $\left(3.63 \times 10^{-3}\right.$ $\mathrm{Scm}^{-1}$ at $303 \mathrm{~K}$ ) than that containing $7 \mathrm{wt} \%$ of cellulose (sample B; $9.61 \times 10^{-4} \mathrm{Scm}^{-1}$ at $303 \mathrm{~K}$ ). This should be due to lower activation energy of the former matrix as shown by the smaller value of VFT parameter ${ }^{37-39}$ (Table II) corresponding to activation energy (B) for ion transport. The difference of activation energy can be explained by considering the higher viscosity of polymer solution under higher polymer concentration as expressed in well-known Houwink-Mark-Sakurada equation $\left(\eta / \mathrm{c}=\mathrm{KM}^{\nu}\right.$; where $\eta=$ viscosity, $\mathrm{c}=$ polymer concentration, $M=$ average molecular weight, $\mathrm{K}$ and $v$ are parameters.).
Ionic conductivity of ion gels composed of different content of $\mathrm{B}(\mathrm{OH})_{3} / \mathrm{C}_{6} \mathrm{~F}_{5} \mathrm{~B}(\mathrm{OH})_{2}$ was evaluated (Figure 2(ii)). When $\mathrm{C}_{6} \mathrm{~F}_{5} \mathrm{~B}(\mathrm{OH})_{2}$ content was greater $\left(\mathrm{B}(\mathrm{OH})_{3}: \mathrm{C}_{6} \mathrm{~F}_{5} \mathrm{~B}(\mathrm{OH})_{2}=\right.$ $1: 2)$ (sample $\mathrm{D})$, ionic conductivity was enhanced $(9.25 \times$ $10^{-4} \mathrm{Scm}^{-1}$ at $\left.303 \mathrm{~K}\right)$ compared with the case where $\mathrm{B}(\mathrm{OH})_{3}: \mathrm{C}_{6} \mathrm{~F}_{5} \mathrm{~B}(\mathrm{OH})_{2}=2: 1$ (sample C; $5.68 \times 10^{-4} \mathrm{Scm}^{-1}$ at $303 \mathrm{~K}$ ) because of high dissociation degree of lithium pentafluorophenylborate unit.

The VFT parameters (Table II) for samples C and D indicate that activation energy of matrix (parameter B) is not largely different between these systems, while sample D showed significantly larger carrier ion number (parameter A). This suggests that the improved ionic conductivity of sample D 
(i)

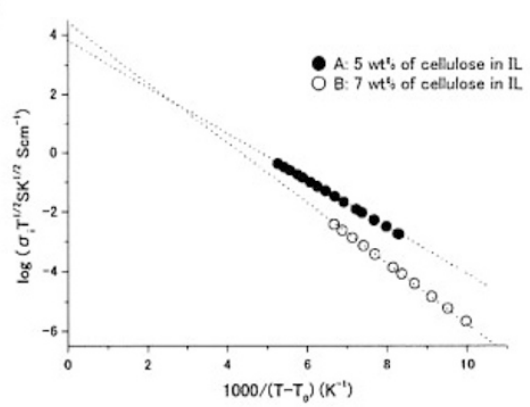

(ii)

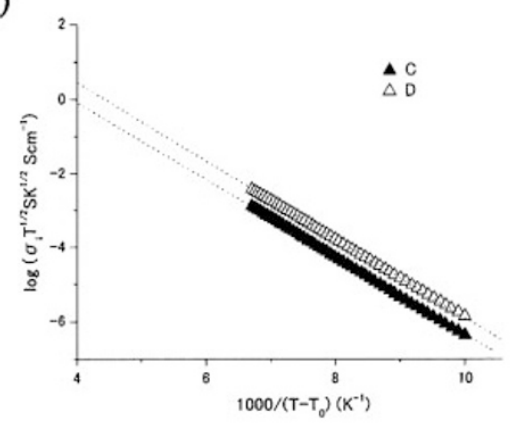

(iii)

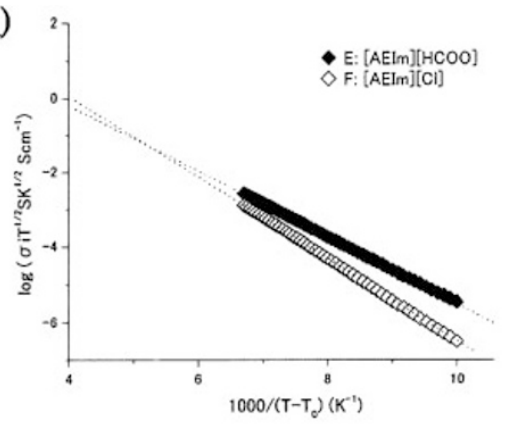

(iv)

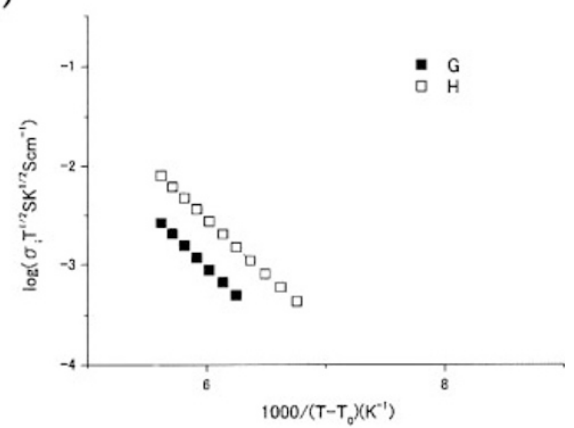

Figure 3. VFT plots for ion gels.

(i) Samples $A$ and $B$ contain 5 wt $\%$ and $7 w t \%$ of cellulose in $[A E I m][C l]$, respectively. $\left(B(O H)_{3}: g l u c o s e ~ u n i t=1: 4, B(O H)_{3}: C_{6} F_{5} B(O H)_{2}: L i O H=1: 2: 3\right)$

(ii) All the samples contain $7 \mathrm{wt} \%$ of cellulose in $[\mathrm{AEIm}][\mathrm{Cl}]$.

Sample C; $\mathrm{B}(\mathrm{OH})_{3}:$ glucose unit $=9: 20, \mathrm{~B}(\mathrm{OH})_{3}: \mathrm{C}_{6} \mathrm{~F}_{5} \mathrm{~B}(\mathrm{OH})_{2}: \mathrm{LiOH}=2: 1: 3$.

Sample D; $\mathrm{B}(\mathrm{OH})_{3}:$ glucose unit $=9: 20, \mathrm{~B}(\mathrm{OH})_{3}: \mathrm{C}_{6} \mathrm{~F}_{5} \mathrm{~B}(\mathrm{OH})_{2}: \mathrm{LiOH}=1: 2: 3$.

(iii) Sample E contains $7 \mathrm{wt} \%$ of cellulose in $[\mathrm{AEIm}][\mathrm{HCOO}]\left(\mathrm{B}(\mathrm{OH})_{3}: \mathrm{glucose}\right.$ unit $\left.=11: 50, \mathrm{~B}(\mathrm{OH})_{3}: \mathrm{LiOH}=1: 1\right)$.

Sample $F$ contains $7 \mathrm{wt} \%$ of cellulose in $[\mathrm{AEIm}][\mathrm{Cl}]\left(\mathrm{B}(\mathrm{OH})_{3}\right.$ :glucose unit $\left.=11: 50, \mathrm{~B}(\mathrm{OH})_{3}: \mathrm{LiOH}=1: 1\right)$.

(iv) Sample G contains 7 wt \% of cellulose in $[\mathrm{AEIm}][\mathrm{HCOO}]\left(\mathrm{B}(\mathrm{OH})_{3}:\right.$ glucose unit $\left.=9: 20, \mathrm{~B}(\mathrm{OH})_{3}: \mathrm{C}_{6} \mathrm{~F}_{5} \mathrm{~B}(\mathrm{OH})_{2}: \mathrm{LiOH}=2: 1: 3\right)$.

Sample $\mathrm{H}$ contains $7 \mathrm{wt} \%$ of cellulose in $[A E I m][\mathrm{HCOO}]\left(\mathrm{B}(\mathrm{OH})_{3}:\right.$ glucose unit $\left.=9: 40, \mathrm{~B}(\mathrm{OH})_{3}: \mathrm{C}_{6} \mathrm{~F}_{5} \mathrm{~B}(\mathrm{OH})_{2}: \mathrm{LiOH}=1: 2: 3\right)$.

Table II. VFT Parameters for Organoboron lon gels

\begin{tabular}{cccrc}
\hline Samples & $T_{\mathrm{o}}(\mathrm{K})$ & $\mathrm{A}\left(\mathrm{Scm}^{-1} \mathrm{~K}^{1 / 2}\right)$ & $\mathrm{B}(\mathrm{K})$ & $\mathrm{RMS}$ \\
\hline A & 183 & 44.45 & 791 & 1.0000 \\
$\mathrm{~B}$ & 183 & 63.22 & 985 & 0.9999 \\
C & 183 & 70.73 & 1065 & 0.9999 \\
D & 183 & 100.0 & 1048 & 0.9999 \\
E & 183 & 28.09 & 883 & 0.9998 \\
F & 183 & 90.22 & 1102 & 0.9999 \\
G & 155 & 49.93 & 1556 & 0.9998 \\
H & 155 & 64.24 & 1117 & 0.9996 \\
\hline
\end{tabular}

is attributed to high dissociation degree of lithium pentafluorophenylborate. Among the ion gels composed of $7 \mathrm{wt} \%$ of cellulose in $[\mathrm{AEIm}][\mathrm{Cl}]$, the best result was observed for sample $\mathrm{B}\left(9.61 \times 10^{-4} \mathrm{Scm}^{-1}\right.$ at $\left.303 \mathrm{~K}\right)$ where $\mathrm{B}(\mathrm{OH})_{3}: \mathrm{C}_{6} \mathrm{~F}_{5^{-}}$ $\mathrm{B}(\mathrm{OH})_{2}=1: 2$ and $\mathrm{B}(\mathrm{OH})_{3} /$ glucose unit ratio $(0.25)$ was also much lower than that of sample D (0.45).

In order to further improve the ionic conductivity of ion gels, preparation of an ion gel using less viscous formate type ionic liquid (1-allyl-3-ethylimidazolium formate) ${ }^{36}$ was also examined. The formate type ionic liquids are capable of dissolving cellulose under mild conditions. Similarly to the case of chloride type ionic liquids, condensation of cellulose with boric acids facilely took place under cellulose composi- tion of $7 \mathrm{wt} \%$ to give the corresponding ion gels at $90^{\circ} \mathrm{C}$. The Arrhenius plot of the ion gel is represented in Figure 2(iii). The obtained ion gel showed significantly higher ionic conductivity (sample E; $1.03 \times 10^{-3} \mathrm{Scm}^{-1}$ at $303 \mathrm{~K}$ ) in comparison with that prepared using chloride type ionic liquid (sample $\mathrm{F}$; $5.35 \times 10^{-4} \mathrm{Scm}^{-1}$ at $303 \mathrm{~K}$ ). This should be due to lower viscosity of formate type ionic liquid than that of chloride type ionic liquids. From the VFT parameters (Table II), carrier ion number (parameter A) for sample $\mathrm{E}$ was lower than that of sample F, however, activation energy of ion transport (parameter B) was also smaller for sample E, which led to higher ionic conductivity of the formate type ion gel. 1-Allyl-3ethylimidazolium formate based ion gels including pentafluorophenylborate (Sample $\mathrm{G}$ and Sample H) were also prepared and their ion conductive properties were evaluated (Figure 2(iv), Figure 3(iv)). Sample $\mathrm{H}$ in which $\mathrm{B}(\mathrm{OH})_{3}$ : $\mathrm{C}_{6} \mathrm{~F}_{5} \mathrm{~B}(\mathrm{OH})_{2}=1: 2$ showed the highest ionic conductivity of $1.98 \times 10^{-3} \mathrm{Scm}^{-1}$ at $303 \mathrm{~K}$ among the ion gels including 7 wt $\%$ of cellulose.

In conclusion, organoboron ion gels were conveniently prepared by the reaction between cellulose and boric acids in ILs. Stable ion gels were obtained under a wide range of composition of starting materials. These ion gels exhibited high ionic conductivity of $3.63 \times 10^{-3}-5.35 \times 10^{-4} \mathrm{Scm}^{-1}$ at $303 \mathrm{~K}$. Because of excellent solubility of poly(saccharide)s in 
chloride type ILs and established reactivity of poly(saccharide)s with boric acids, use of poly(saccharide)s was quite beneficial in convenient design of ion gels including highly dissociable lithium borate structure.

Acknowledgment. The financial support for this study by a Grand-in-Aid for Scientific Research from the Ministry of Education, Culture, Science, Sports, and Technology, Japan (No. 19685018 and No. 20031013) is gratefully acknowledged.

Received: November 11, 2008 Accepted: February 2, 2009 Published: March 18, 2009

\section{REFERENCES}

1. T. Welton, Chem. Rev., 99, 2071 (1999).

2. H. Ohno, Bull. Chem. Soc. Jpn., 79, 1665 (2006).

3. "Electrochemical Aspects of Ionic Liquids," H. Ohno, Ed., WileyInterscience, New York, 2005.

4. H. Ohno and K. Ito, Chem. Lett., 751 (1998).

5. M. Yoshizawa and H. Ohno, Chem. Lett., 889 (1999).

6. M. Hirao, K. Ito, and H. Ohno, Electrochim. Acta, 45, 1291 (2000).

7. M. Hirao, K. Ito-Akita, and H. Ohno, Polym. Adv. Technol., 11, 534 (2000).

8. M. Yoshizawa and H. Ohno, Electrochim. Acta, 46, 1723 (2001).

9. M. Yoshizawa, W. Ogiwara, and H. Ohno, Polym. Adv. Technol., 13, 589 (2002).

10. J. Fuller, A. C. Breda, and R. T. Carlin, J. Electrochem. Soc., 144, L67 (1997).

11. R. T. Carlin and J. Fuller, Chem. Commun., 1345 (1997).

12. J. Fuller, A. C. Breda, and R. T. Carlin, J. Electroanal. Chem., 459, 29 (1998).

13. A. Noda and M. Watanabe, Electrochim. Acta, 45, 1265 (2000).

14. T. Tsuda, T. Nohira, Y. Nakamura, K. Matsumoto, R. Hagiwara, and Y. Ito, Solid State Ionics, 149, 295 (2002).

15. H. Ohno, M. Yoshizawa, and W. Ogiwara, Electrochim. Acta, 48, 2079 (2003).

16. M. A. S. Azizi, F. Alloin, W. Gorecki, J.-Y. Sanchez, and A.
Dufresne, J. Phys. Chem. B, 108, 10845 (2004).

17. R. P. Swatloski, S. K. Spear, J. D. Holbrey, and R. D. Rogers, J. Am. Chem. Soc., 124, 4974 (2002).

18. T. Mizumo, E. Marwanta, N. Matsumi, and H. Ohno, Chem. Lett., 1360 (2004).

19. H. Zhang, J. Wu, J. Zhang, and J. He, Macromolecules, 38, 8272 (2005).

20. D. Klemn, B. Philipp, T. Heinze, U. Heinze, and W. Wagenknecht, "Comprehensive Cellulose Chemistry," Volume 2, Wiley-VCH, Weinheim, 1998.

21. T. Sato, Y. Tsujii, T. Fukuda, and T. Miyamoto, Macromolecules, 25, 3890 (1992).

22. W. Chein, C. Lu, and R. Pelton, Biomacromolecules, 7, 701 (2006).

23. H. S. Lee, X. Q. Yang, C. L. Xiang, and J. MacBreen, J. Electrochem. Soc., 145, 2813 (1998).

24. J. McBreen, H. S. Lee, X. Q. Yang, and X. Sun, J. Power Sources, 89 163 (2000).

25. M. A. Mehta and T. Fujinami, Chem. Lett., 915 (1997).

26. X. Sun and C. A. Angell, Electrochim. Acta, 46, 1467 (2001).

27. T. Hirakimoto, M. Nishiura, and M. Watanabe, Electrochim. Acta, 46, 1609 (2001).

28. N. Matsumi, K. Sugai, and H. Ohno, Macromolecules, 35, 5731 (2002).

29. N. Matsumi, K. Sugai, and H. Ohno, Macromolecules, 36, 2321 (2003).

30. N. Matsumi, M. Miyake, and H. Ohno, Chem. Commun., 2852 (2004).

31. N. Matsumi, M. Nakashiba, T. Mizumo, and H. Ohno, Macromolecules, 38, 2040 (2005).

32. A. Narita, W. Shibayama, K. Sakamoto, T. Mizumo, N. Matsumi, and H. Ohno, Chem. Commun., 1926 (2006).

33. W. Xu and C. A. Angell, Electrochem. Solid-State Lett., 4(1), E1 (2001).

34. T. J. Barbarich and P. F. Driscroll, Electrochem. Solid-State Lett., 6, A113 (2003)

35. T. J. Barbarich, P. F. Driscroll, S. Izquierdo, L. N. Zakharov, C. D. Incarvito, and A. L. Rheingold, Inorg. Chem., 43, 7764 (2004).

36. Y. Fukaya, A. Sugimoto, and H. Ohno, Biomacromolecules, 7, 3295 (2006).

37. H. Vogel, Phys. Z., 22, 645 (1921).

38. G. S. Fulcher, J. Am. Ceram. Soc., 8, 339 (1925).

39. G. Tamman and W. Z. Hesse, Anorg. Allg. Chem., 156, 245 (1926). 